\title{
POSTCARDS: A SOURCE FOR ABORIGINAL BIOGRAPHY
}

\author{
Christine Cane and Niel Gunson
}

The obvious link between postcards and Aboriginal history is the photographic and descriptive content of the cards themselves. During the latter part of the nineteenth century and well into this century photocards ${ }^{1}$ and postcards ${ }^{2}$ were printed, largely for overseas consumption, which showed scenes of Aboriginal life or portraits of Aboriginal identities. Many of these cards are of value as often being the only records of what they portray. ${ }^{3}$

Picture postcards came into their own in the late 1890s but it was only in 1902 that cards were first made in Britain with divided backs for short messages, and this system was only introduced into Australia in $1905 .^{4}$ While letters were usually destroyed, picture postcards were collectable and often preserved in special albums. The messages on these cards, though seemingly trivial in content, can often become records of social significance.

A collection of twenty-two postcards, eight written in the Diyari (Dieri) language, was given to the Mortlock Library of South Australiana, Adelaide, in 1985. These postcards were sent during the period 1907 to 1914 by Rebecca Maltilina of the Diyari tribe to her friend Dorothea or Dorrie Ruediger. Rebecca and Dorothea grew up on the Bethesda Lutheran Mission at Lake Killalpaninna, Coopers Creek, where they became fast friends, conversing with each other in both Diyari and English. The friendship continued when Rebecca removed to Natimuk in Victoria with one of the Lutheran pastors and his family.

Dorothea Ruediger's life is well documented. She belonged to a South Australian family well known for its links with the Diyari Aborigines. Dorothea Elizabeth was the seventh of the nine children of Gottlieb Theodor Ruediger (1853-1937) and his wife Anna Bertha Christiana Hameister (1859-1945) and was born at Neales Flat on 9 September $1892 .^{5}$ Theodor Ruediger was a sheep farmer until 1896 when he joined the Bethesda Lutheran Mission as teamster and head stockman. His young family was soon absorbed in the mission

Christine Cane holds a BA DipEd, Macquarie University, majoring in Australian and American History, and a Graduate Diploma in Library Studies, South Australian Institute of Technology. She worked as a teacher-librarian for six years in secondary schools in Sydney and Adelaide. In January 1985 Christine was appointed Field Officer with the Mortlock Library of South Australiana.

Niel Gunson is Senior Fellow in the Department of Pacific and Southeast Asian History, The Australian National University, and was Foundation Chairman of Aboriginal History Incorporated.

1 These were photographs with descriptions on the reverse and no space for writing, designed to accom pany correspondence.

2 These included official 'postal cards' and privately printed 'picture cards'.

3 Aboriginal subjects on Australian postcards are listed in Vukovic 1983:9-10.

4 Dûval 1978:21; Vukovic 1983:3,5.

5 Munchenberg 1975. 
ABORIGINAL HISTORY $1986 \quad$ 10:2

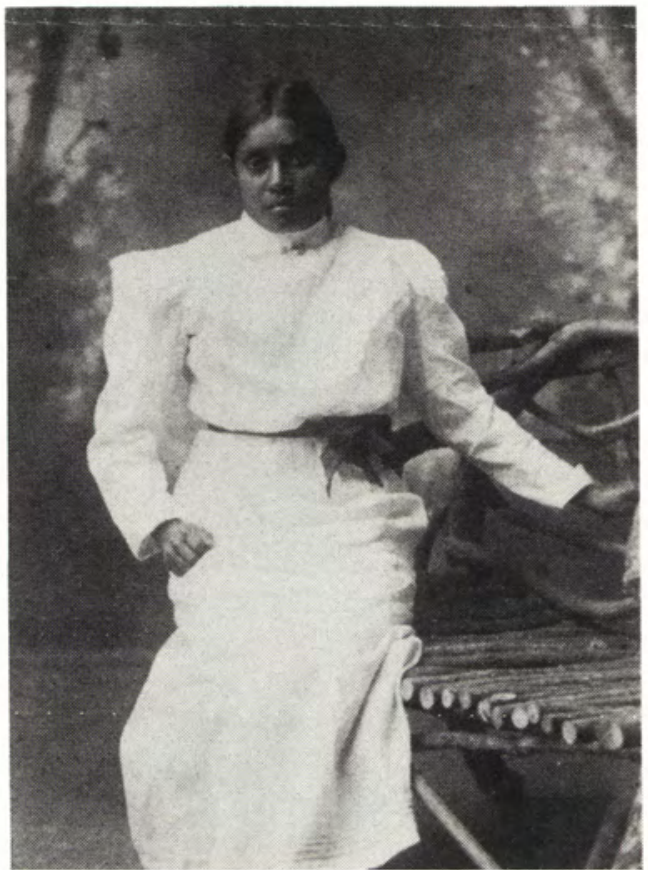

Rebecca Maltilina (Studio portrait by Wellesley Brown, Horsham), courtesy South Australian Museum, Adelaide

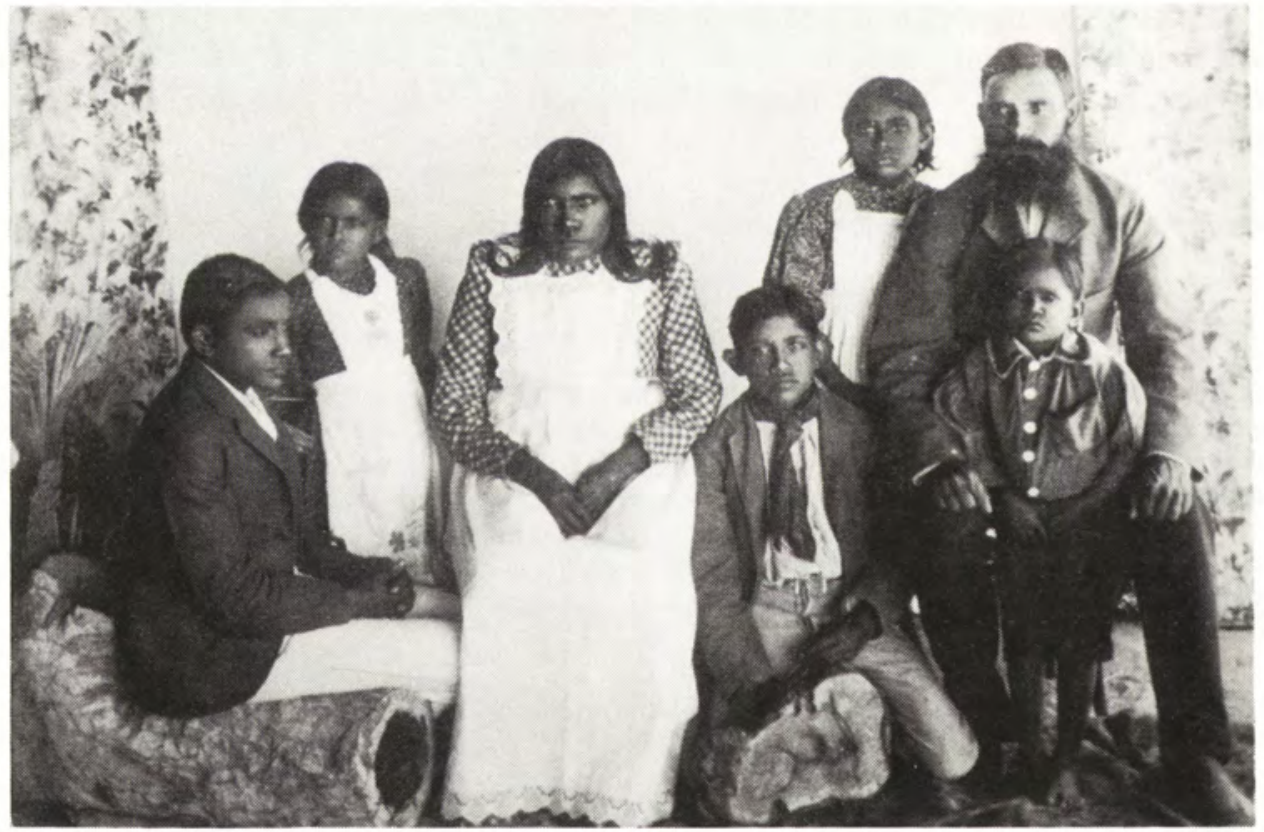

Maltilina family circa 1900

(from left) Martin, Selma, Anna, Gottlieb, Rebecca, Tim with youngest child, courtesy South Australian Museum, Adelaide 


\section{POSTCARDS}

community. Young Dorothea appears as Dora in a story told by Ben Murray to Peter Austin in which she used her knowledge of Diyari to play a trick on an Afghan. ${ }^{6}$ Ben Murray confirmed that Dora was fluent in Diyari.

The Ruediger family remained at the station until 1912 when, because of Anna's health, they moved to Spring Hut Creek near Robertstown, west of Clare, where Theodor became a contractor for the local council. Dorothea's eldest sister Rosina married Theodor Vogelsang (1878-1955), the storekeeper and postmaster at Bethesda Mission, afterwards caretaker of the Aboriginal section of the Museum in Adelaide, and translater of manuscripts dealing with the life and customs of the Diyari people. ${ }^{7}$ Dorothea married James Honeychurch, a dairy farmer in the Mount Barker district, and died on 18 February 1985 having raised a family of five sons and one daughter.

Rebecca's life is less precisely documented. She was one of at least five children of Aboriginal parents. Her father's name was Tim Maltilina (Maltalinna) and a note pencilled by Norman Tindale on the back of a photograph of the family group reads Maltilinna Tim = Merrick or Morick. $1 / 2$ caste. Salt Ck. Diamantina'8 Tim Maltilina probably assumed the European name of Merrick at some point and his sons Martin and Gottlieb were known as Merricks (as presumably was the third son). The two girls were Rebecca (the elder) and Selma. Rebecca clearly continued to identify as Maltilina, rather than Merrick for some time. Martin Merrick married and moved to Waikerie (or a small town nearby named Low Bank) on the Murray River and Rebecca was also living there is 1930.

Rebecca's date of birth was about 1887. A census of Killalpaninna residents taken in 1886 shows that at that date her father Tim Maltilina was nineteen years old and Anna, her mother, was sixteen years old. ${ }^{9}$ Both parents could read and write and had been baptised. Their eldest son Martin was then seven months old. Rebecca was about a year younger than Martin, and there is a reference to 'Rebecca's mother' in the diary of the missionary Johann Reuther for 9 September $1889 .{ }^{10}$ In 1904 Rebecca accompanied the Lutheran Pastor Loehe and his family to Natimuk. Loehe was recovering from rheumatic fever and had been advised to move to a warmer climate. His colleague Pastor Bogner suggested that he take 'one of the native girls' to assist him and his wife with their young family. ${ }^{11}$

Rebecca evidently excelled as a swimmer, winning all the swimming contests at the Natimuk annual regatta and swimming competition. 'She received accolades from her fellow Natimuk competitors, but the girls from Horsham were very jealous. ${ }^{12}$ In 1922 Loehe was appointed principal of Emmanuel College and Seminary in Jeffcott Street, North Adelaide. Rebecca accompanied the family to Adelaide and stayed with them there for about three more years. Between 1926 and 1942 she worked around Adelaide and died in the Royal Adelaide Hcspital in 1942 'aged fifty-two'.

6 Murray anl Austin 1981:75-79.

7 Munchenbrg 1985.

8 Tindale Callection.

9 Mission Committee 1886:45.

10 Pers. comn. Philip Jones, Curator, Aboriginal History, South Australian Museum. The authors are grateful to Philip Jones for providing information from the Museum's holdings.

11 Cane 1985; Lloyd 1985.

12 Cane 1985 
The postcards celebrate the close friendship between the two women. Aboriginal and European children were given equal educational opportunities on the mission and, in the words of Pastor Scherer, 'they very often played together from an early age, fought, shared confidences etc - literally grew up together - there was a spirit of mutual respect, trust and co-operation on the mission stations. ${ }^{13}$ The postcards cease before Dorothea's marriage to James Honeychurch during or shortly after the First World War.

Most of the postcards contain simple messages in English, showing a growing confidence in the handwriting. A later one tells of a recent swimming triumph:

Dear Dorrie/ Many thanks indeed for your nice letter I am writing a card this time but will send a letter next time. I went in our swimming Carnival \& got first prize trophy $=£ 1.1$ It will be nice for you to have a holiday again, you should come over here. I will close now, with much love/ From Rebecca.

The eight cards written in the Diyari language appear to have been written during much the same time span as the English ones, but are fuller in content and suggest that the letters which they wrote each other (presumably destroyed) were also in the Diyari language. In these cards Rebecca tends to sign with her initial and signs one of them as R. Maltilina.

While postcards seldom contain many words they frequently tell of specific events and movements. They also encapsulate important relationships. Those with Aboriginal language messages should be valued not only as records of rare dialects but also as useful links in reconstructing Aboriginal biographies.

13 ibid.

\section{BIBLIOGRAPHY}

Cane, Christine. Notes of interview with the Reverend Philip A. Scherer, Archivist, Lutheran Archives, 17 May 1985.

Dûval, William with Valerie Monahan. Collecting postcards in colour 1894-1914. Poole, Dorset, 1978.

Lloyd, Paul. 'Little messages that put flesh on history's bones'. The Advertiser (Adelaide), 18 July 1985.

Mission Committee of the Evangelical Lutheran Immanual Synod in South Australia. Story of the Evangelical Lutheran Mission in South Australia, together with information on the land and the people. Tanunda, 1886.

Munchenberg, Reg and Marlene Munchenberg. Our Family 125 years in Australia 1850-1985, Christian and Anna Elisabeth Ruediger, their son and daughters Gottfried Ruediger, Anna Felix, Elisabeth Schenke, Dorothea Reiss: a history and family tree of their known descendants. [Adelaide, 1985.]

Murray, Ben and Peter Austin. 'Afghans and Aborigines: Diyari texts', Aboriginal History, 5 (1), 1981 : $71-79$.

Tindale Collection, Anthropology Archives, South Australian Museum, Adelaide.

Vukovic, Nick. Collecting Australian postcards: a guide to values. Collingwood, Victoria, 1983. 